\title{
Role of phosphate-solubilizing microorganisms in sustainable agriculture - A review
}

\author{
Mohammad Saghir KHAN*, Almas ZAIDI, Parvaze A. WANI \\ Department of Agricultural Microbiology, Faculty of Agricultural Sciences, Aligarh Muslim University, Aligarh U.P., 202002, India
}

(Accepted 18 May 2006)

\begin{abstract}
Compared with the other major nutrients, phosphorus is by far the least mobile and available to plants in most soil conditions. Although phosphorus is abundant in soils in both organic and inorganic forms, it is frequently a major or even the prime limiting factor for plant growth. The bioavailability of soil inorganic phosphorus in the rhizosphere varies considerably with plant species, nutritional status of soil and ambient soil conditions. To circumvent phosphorus deficiency, phosphate-solubilizing microorganisms (PSM) could play an important role in supplying phosphate to plants in a more environmentally-friendly and sustainable manner. The solubilization of phosphatic compounds by naturally abundant PSM is very common under in vitro conditions; the performance of PSM in situ has been contradictory. The variability in the performance has thus greatly hampered the large-scale application of PSM in sustainable agriculture. Numerous reasons have been suggested for this, but none of them have been conclusively investigated. Despite the variations in their performance, PSM are widely applied in agronomic practices in order to increase the productivity of crops while maintaining the health of soils. This review presents the results of studies on the utilization of PSM for direct application in agriculture under a wide range of agro-ecological conditions with a view to fostering sustainable agricultural intensification in developing countries of the tropics and subtropics.
\end{abstract}

\section{INTRODUCTION}

As the world's human population continues to increase, the demands placed upon agriculture to supply future food will be one of the greatest challenges facing the agrarian community. In order to meet this challenge, a great deal of effort focusing on the soil biological system and the agro-ecosystem as a whole is needed to understand better the complex processes and interactions governing the stability of agricultural land. At the present time, food is (generally) not in short supply (rather, there is a lack of timely distribution of foods to areas of need) due, in part, to high-input agriculture, which in turn caused the green revolution. The green revolution has been one of the most profoundly successful human activities resulting in global food security and, consequently, transformed some of the developing countries, such as India, from being food-deficient to having a food surplus. However, the consistent and alarming increase in the human population has again threatened the world's food security. There is therefore an urgent need for a second green revolution to increase the food production by around $50 \%$ in the next 20 years in order to sustain the population pressure (Vasil, 1998; Leisinger, 1999).

Chemical fertilizers, e.g., manufactured water-soluble phosphatic (WSP) fertilizers (superphosphates) have played a significant role in the green revolution and are commonly recommended to correct phosphorus deficiencies. Most develop- ing countries, however, import these fertilizers, which are often in limited supply and represent a major outlay for resource-poor farmers. In addition, intensification of agricultural production in these countries necessitates the addition of phosphate not only to increase crop production but also to improve soil phosphatic status in order to avoid further soil degradation. Moreover, the use of chemical fertilizers is reaching the theoretical maximum use beyond which there will be no further increase in crop yields (Ahmed, 1995). However, it is becoming increasingly clear that conventional agricultural practices cannot sustain the production base, a healthy plantsoil system, for too long; while, to augment crop productivity, agronomists depend heavily on chemical fertilizers. In this context, after nitrogen, phosphorus is an essential plant nutrient whose deficiency restricts crop yields severely. Tropical and subtropical soils are predominantly acidic, and often extremely phosphorus-deficient (Gaume, 2000) with high phosphorus sorption (fixation) capacities. On average, most mineral nutrients in soil solution are present in millimolar amounts but phosphorus is present only in micromolar or lesser quantities (Ozanne, 1980). The low levels of phosphorus are due to high reactivity of soluble phosphate with other elements. For instance, in acidic soils phosphorus is associated with aluminium and iron compounds (Norrish and Rosser, 1983), whereas calcium phosphate is the predominant form of inorganic phosphate in calcareous soils (Lindsay et al., 1989).

* Corresponding author: khanms17@ rediffmail.com 
Organic phosphate may also make up a large fraction of soluble phosphate, as much as $50 \%$ in soils with high organic matter content (Barber, 1984). Since the indiscriminate and excessive application of chemical fertilizers has led to health and environmental hazards, agronomists are desperate to find alternative strategies that can ensure competitive yields while protecting the health of soils. This new approach to farming, often referred to as sustainable agriculture, requires agricultural practices that are friendlier to the environment and that maintain the long-term ecological balance of the soil ecosystem. In this context, use of microbial inoculants (biofertilizers) including PSM in agriculture represents an environmentallyfriendly alternative to further applications of mineral fertilizers. A continued exploration of the natural biodiversity of soil microorganisms and the optimization/manipulation of microbial interactions in the rhizosphere represents a prerequisite step to developing more efficient microbial inoculants with phosphorus-solubilizing ability.

\section{URGENT NEED FOR PHOSPHATE- SOLUBILIZING MICROORGANISMS IN PLANT PHOSPHATE NUTRITION}

The production of chemical phosphatic fertilizers is a highly energy-intensive process requiring energy worth US \$ 4 billion per annum in order to meet the global need (Goldstein et al., 1993). The situation is further compounded by the fact that almost 75-90\% of added phosphatic fertilizer is precipitated by metal cation complexes present in the soils (Stevenson, 1986). Further, it has been suggested that the accumulated phosphates in agricultural soils are sufficient to sustain maximum crop yields worldwide for about 100 years (Goldstein et al., 1993). Thus, the dependence of fertilizer production on a fossil energy source and the prospects of the diminishing availability of costly input of fertilizer production in years to come have obviously brought the subject of mineral phosphate solubilization (mps) to the forefront. Hence, it is imperative to explore alternative phosphatic sources. Under diverse soil and agro-climatic conditions, the organisms with phosphate-solubilizing abilities have proved to be an economically sound alternative to the more expensive superphosphates and possess a greater agronomic utility. The microbial system can siphon out appreciable amounts of nutrients from the natural reservoir and enrich the soil with the important but scarce nutrients. The crop microbial ecosystem can thus be energized in sustainable agriculture with considerable ecological stability and environmental quality. The organisms with phosphate-solubilizing potential increase the availability of soluble phosphate and can enhance plant growth by increasing the efficiency of biological nitrogen fixation or enhancing the availability of other trace elements such as iron, zinc, etc., and by production of plant growth-promoting regulators (Sattar and Gaur, 1987; Kucey et al., 1989; Ponmurugan and Gopi, 2006).

\section{NATURE OF PHOSPHATIC BIOFERTILIZERS}

The majority of crop plants have been found to be positively affected by the association with rhizospheric microorganisms under phosphorus-deficient conditions. This association could result either in improved uptake of the available phosphates or rendering unavailable phosphorus sources accessible to the plant. Arbuscular mycorrhizae (AM) belong to the former category, while the latter category includes numerous bacteria and fungi capable of solubilizing insoluble mineral phosphate. In the present section, an attempt is made to identify such natural phosphate-solubilizing organisms.

\subsection{Phosphate-solubilizing microorganisms}

Microorganisms are an important component of soil and directly or indirectly influence the soil's health through their beneficial or detrimental activities. Rhizospheric microorganisms mediate soil processes such as decomposition, nutrient mobilization and mineralization, storage release of nutrients and water, nitrogen fixation and denitrification. Furthermore, the organisms possessing a phosphate-solubilizing ability can also convert the insoluble phosphatic compounds into soluble forms (Kang et al., 2002; Pradhan and Sukla, 2005) in soil and make them available to the crops. The role of rhizospheric organisms in mineral phosphate solubilization was known as early as 1903 . Since then, there have been extensive studies on mineral phosphate solubilization by naturally abundant rhizospheric microorganisms. Important genera of mineral phosphate solubilizers include Bacillus and Pseudomonas (Illmer and Schinner, 1992), while Aspergillus and Penicillium form the important fungal genera (Motsara et al., 1995). Recently, the nematofungus Arthrobotrys oligospora was tested in vitro and in vivo for its ability to solubilize Kodjari rock phosphate (Burkina Faso, KRP), Togolese rock phosphate (Senegal TRP) and Tilemsi rock phosphate (Mali TIRP). All three types of rock phosphates were solubilized by the fungus and demonstrated the ability to solubilize additional phosphate from rock phosphates in vivo as well (Duponnois et al., 2006). Most of the impact with the use of microorganisms as biofertilizers has been directed towards understanding biological nitrogen fixation. In contrast, the fundamental work on phosphate solubilization by nodule bacteria has been substantially less; though it is known that phosphorus is the most limiting factor for nitrogen fixation by Rhizobium-legume symbiosis. There are only a few reports of phosphate solubilization by Rhizobium (Halder et al., 1991; Abd-Alla, 1994; Chabot et al., 1996) and the non-symbiotic nitrogen fixer, Azotobacter (Kumar et al., 2001). Phosphate-solubilizing microorganisms are ubiquitous, whose numbers vary from soil to soil. In soil, phosphate-solubilizing bacteria constitute 1-50\% and fungi $0.5 \%-0.1 \%$ of the total respective population. Generally, the phosphate-solubilizing bacteria outnumber phosphate-solubilizing fungi by 2-150 times (Kucey, 1983). The high proportion of PSM is concentrated in the rhizospheres and is known to be more metabolically active than those isolated from sources other than the rhizosphere (Vazquez et al., 2000). Conversely, the salt-, $\mathrm{pH}$ - and temperature-tolerant phosphate-solubilizing bacteria have been reported to be maximum in the rhizoplane followed by the rhizosphere and root-free soil in alkaline soils (Johri et al., 1999). The PSM strains with these stressed properties should therefore serve as an excellent model for studying the physiological, biochemical and molecular mechanisms of phosphate solubilization under stressed ecosystems. Further, it 

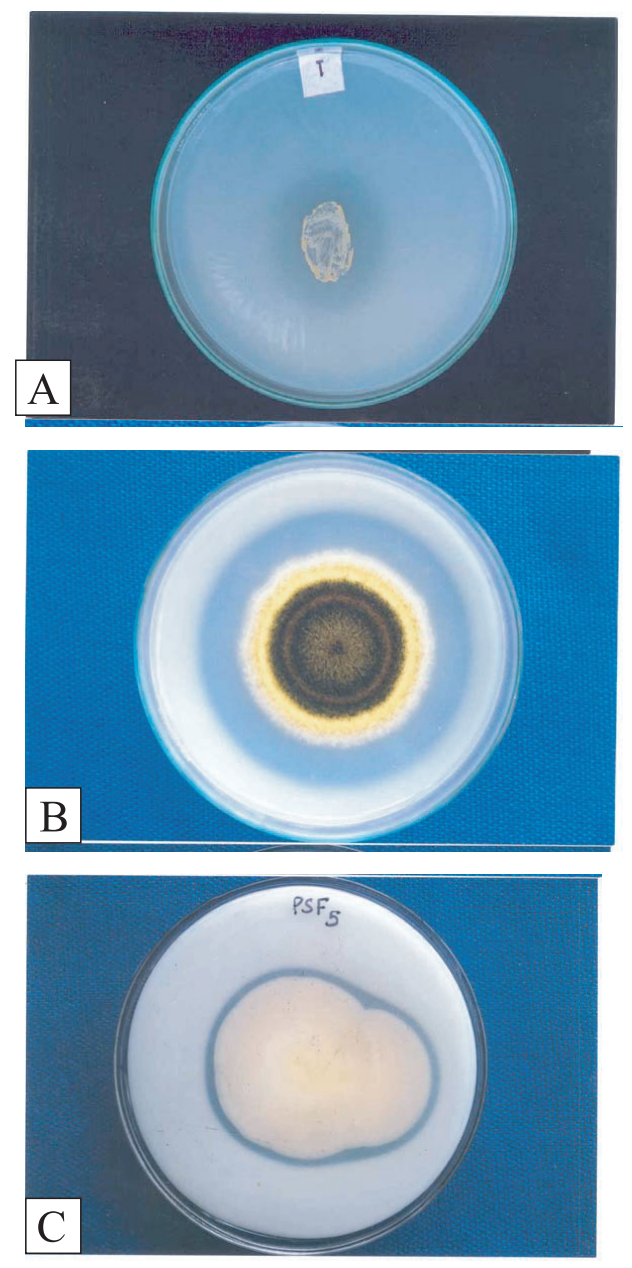

Figure 1. Solubilization of insoluble $\mathrm{P}$ on Pikovskaya medium by phosphate-solubilizing bacteria (A) and fungi (B, C).

has been observed that phosphate-solubilizing bacteria upon repeated sub-culturing lose the phosphate-solubilizing activity, but such losses have not been observed in phosphate-solubilizing fungus (Kucey, 1983). In general, phosphate-solubilizing fungi produce more acids and consequently exhibit greater phosphate-solubilizing activity than bacteria in both liquid and solid media (Venkateswarlu et al., 1984). The phosphate-solubilizing ability of PSM also depends on the nature of the nitrogen source used in the media, with greater solubilization in the presence of ammonium salts than when nitrate is used as nitrogen source. This has been attributed to the extrusion of protons to compensate for ammonium uptake, leading to a decreased extra-cellular pH (Roos and Luckner, 1984). In some cases, however, ammonium can lead to a decrease in phosphorus solubilization (Reyes et al., 1999).

\subsubsection{Search for phosphate-solubilizing microorganisms}

Phosphate-solubilizing microorganisms can be isolated using serial dilutions or enrichment culture techniques on/in Pikovskaya medium (Pikovskaya, 1948) from non-rhizosphere and rhizosphere soils, the rhizoplane, and also from other environments, such as rock phosphate deposit area soil and marine environments (Gaur, 1990). Upon incubation of the organisms on the solid plates containing insoluble phosphate, PSM are detected by the formation of clear halos around their colonies (Fig. 1). Recently, a few other methods for the isolation and selection of PSM have been suggested (Gupta et al., 1994; Nautiyal, 1999). Since certain strains of phosphate-solubilizing organisms exhibit manyfold variation in phosphate-solubilizing activity and instability with regard to their phosphate-solubilizing activity (Illmer and Schinner, 1992), they are repeatedly sub-cultured to test the persistence of their phosphate-solubilizing potential. Once the efficient phosphate-solubilizing organisms are selected, they are tested for their ability to solubilize insoluble phosphate under liquid culture medium. Finally, the selected efficient phosphate-solubilizing cultures are used for making the inoculants and their performance under pot/field conditions is tested against various crops.

\subsubsection{Mechanism of phosphate solubilization - an overview}

Many researchers have quantitatively investigated the ability of PSM to solubilize insoluble phosphate in pure liquid culture medium (Whitelaw, 2000; Narula et al., 2000). The microbial solubilization of soil phosphorus in liquid medium has often been due to the excretion of organic acids (Tab. I). For instance, oxalic acid, citric acid, lactic acid, etc. in liquid culture filtrates were determined by paper chromatography or thin layer chromatography or by high-performance liquid chromatography and certain enzymatic methods to allow more accurate identification of unknown organic acids (Gyaneshwar et al., 1998). Such organic acids can either directly dissolve the mineral phosphate as a result of anion exchange of $\mathrm{PO}_{4}{ }^{2-}$ by acid anion or can chelate both iron and aluminium ions associated with phosphate (Omar, 1998). In certain cases phosphate solubilization is induced by phosphate starvation (Gyaneshwar et al., 1999). However, no definite correlation between the acids produced by PSM and amounts of phosphate solubilized are reported (Asea et al., 1988). The role of organic acids produced by PSM in solubilizing insoluble phosphate may be due to the lowering of $\mathrm{pH}$, chelation of cations and by competing with phosphate for adsorption sites in soil (Nahas, 1996). Inorganic acids, e.g., hydrochloric acid can also solubilize phosphate but they are less effective compared with organic acids at the same $\mathrm{pH}$ (Kim et al., 1997). However, acidification does not seem to be the only mechanism of solubilization, as the ability to reduce the $\mathrm{pH}$ in some cases did not correlate with the ability to solubilize mineral phosphates (Subba Rao, 1982). The chelating ability of organic acids is also important, as it has been shown that the addition of $0.05 \mathrm{M}$ EDTA to the medium has the same solubilizing effect as inoculation with Penicillium bilaii (Kucey, 1988). Among nodule bacteria (e.g., Rhizobium/ Bradyrhizobium), the phosphate-solubilizing activity of Rhizobium was associated with the production of 2-ketogluconic acid which was abolished by the addition of $\mathrm{NaOH}$, indicating that the phosphate-solubilizing activity of this organism was entirely due to its ability to reduce the $\mathrm{pH}$ of the medium (Halder and Chakrabarty, 1993). However, the detailed biochemical and molecular mechanisms of phosphate solubilization by symbiotic nodule bacteria are not known. 
Table I. A brief summary of production of principal organic acids by phosphate-solubilizing microorganisms.

\begin{tabular}{|c|c|c|}
\hline Organism & Predominant acids & References \\
\hline \multicolumn{3}{|l|}{ Phosphate-solubilizing fungi and actinomycetes } \\
\hline Aspergillus flavus, A. niger, Penicillium canescens & Oxalic, citric, gluconic succinic & Maliha et al., 2004 \\
\hline A. niger & Succinic & Vazquez et al., 2000 \\
\hline Penicillium rugulosum & Gluconic & Reyes et al., 1999 \\
\hline Penicillium radicum & Gluconic & Whitelaw et al., 1999 \\
\hline Penicillium variable & Gluconic & Vassilev et al., 1996 \\
\hline A. niger & Citric, oxalic, gluconic & Illmer et al., 1995 \\
\hline A. awamori, A. foetidus, A. terricola, A. amstelodemi, A. tamari & Oxalic, citric & Gupta et al., 1994 \\
\hline A. japonicus, A. foetidus & Oxalic, citric, gluconic succinic, tartaric & Singal et al., 1994 \\
\hline Penicillium bilaji & Citric, oxalic & Cunningham and Kuiack, 1992 \\
\hline A. niger, $P$. simplicissimum & Citric & Burgstaller et al., 1992 \\
\hline A. awamori, P. digitatum & Succinic, citric, tartaric & Gaur, 1990 \\
\hline Penicillium sp. & Oxalic, itaconic & Parks et al., 1990 \\
\hline Scwaniomyces occidentalis & Succinic, fumaric, citric, tartaric, $\alpha$-ketbutyric & Gaur, 1990 \\
\hline A. niger & Succinic & Venkateswarlu et al., 1984 \\
\hline Aspergillus sp., Penicillium sp., Chaetomium nigricoler & Oxalic, succinic, citric, 2-ketogluconic & Banik and Dey, 1983 \\
\hline Streptomyces & Lactic, 2-ketogluconic & Banik and Dey, 1982 \\
\hline A. fumigatus, A. candidus & Oxalic, tartaric, citric & Banik and Dey, 1982 \\
\hline \multicolumn{3}{|l|}{ Phosphate-solubilizing bacteria } \\
\hline Enterobacter intermedium & 2-ketogluconic & Hoon et al., 2003 \\
\hline $\begin{array}{l}\text { Bacillus amyloliquefaciens, B. licheniformis, B. atrophaeus, } \\
\text { Penibacillus macerans, Vibrio proteolyticus, xanthobacter agilis, } \\
\text { Enterobacter aerogenes, E. taylorae, E. asburiae, Kluyvera } \\
\text { cryocrescens, Pseudomonas aerogenes, Chryseomonas luteola }\end{array}$ & Lactic, itaconic, isovaleric, isobutyric, acetic & Vazquez et al., 2000 \\
\hline Pseudomonas cepacia & Gluconic , 2-ketgluconic & Bar-Yosef et al., 1999 \\
\hline Bacillus polymyxa, B. licheniformis, Bacillus spp. & Oxalic, citric & Gupta et al., 1994 \\
\hline Pseudomonas striata & $\begin{array}{c}\text { Malic, glyoxalic, succinic, fumaric, tartaric, } \\
\alpha \text {-ketobutyric }\end{array}$ & Gaur, 1990 \\
\hline Arthrobacter sp. & Oxalic, malonic & Banik and Dey, 1982 \\
\hline Bacillus firmus & 2-ketogluconic, succinic & Banik and Dey, 1982 \\
\hline Micrococcus spp. & Oxalic & Banik and Dey, 1982 \\
\hline Bacillus subtilis, Bacillus spp. & Oxalic, succinic, citric, 2-ketgluconic & Banik and Dey, 1983 \\
\hline
\end{tabular}

\subsubsection{Production of phosphate-solubilizing microorganism inoculants}

Efficient PSM cultures are mass-produced for supply to the farmers as microphos. The production of microphos, i.e., a preparation containing microorganisms with phosphate-solubilizing activity, includes three phases: the first concerns selection and testing of phosphate-solubilizing strains; secondly, inoculant preparation, including selection and processing of the material carrier and mass culture of PSM; and thirdly, quality control procedures and distribution. For microphos production, peat, farmyard manure (FYM), soil and cow dung cake powder have been suggested as suitable carriers (Kundu and Gaur, 1981). Finally, the cultures are packed in polybags and can safely be stored for about three months at $30 \pm 2{ }^{\circ} \mathrm{C}$. In India, a microbial preparation termed Indian Agricultural Research Institute (IARI) microphos culture (Gaur, 1990) was developed that contained two efficient phosphate-solubilizing bacteria (Pseudomonas striata and Bacillus polymyxa) and three phosphate-solubilizing fungi (Aspergillus awamori, A. niger and Penicillium digitatum).

\subsection{Mycorrhizae}

Phosphorus is an essential element for plant nutrition and it can only be assimilated as soluble phosphate. However, in natural conditions, most of the phosphatic soil content (soil mineral phosphate, i.e., rock phosphate and organic phosphorus) is poorly soluble. Moreover, among soil microorganisms, arbuscular mycorrhizal fungi have been found to be essential components of sustainable soil-plant systems (Schreiner et al., 2003). Arbuscular mycorrhizal fungi increased plant uptake of phosphate (Bolan, 1991), micronutrients (Burkert and Robson, 1994), nitrogen (Barea et al., 1991) and soil aggregation (Tisdall, 1994), and act as antagonists against some plant pathogens (Duponnois et al., 2005). Moreover, it has been demonstrated that plants inoculated with arbuscular mycorrhizal fungi utilize more soluble phosphate from rock phosphate than noninoculated plants (Antunes and Cardoso, 1991; Guissou et al., 2001). The main explanation is that mycorrhizas developed an extramatrical mycelium, which increased the root phosphateabsorbing sites (Bolan, 1991). Since arbuscular mycorrhizal fungi are obligate endosymbionts and live on carbohydrates 
obtained from the root cells, all soil factors affecting plant growth and physiology will also modify fungal activity and, in turn, influence the structure and functioning of bacterial communities (Azaizeh et al., 1995). It is now well established that arbuscular mycorrhizal fungi modify root functions (i.e. root exuadation) (Marshner et al., 1997), change the carbohydrate metabolism of the host plant (Schachar-Hill et al., 1995) and influence rhizosphere populations (Hobbie, 1992). Microorganisms in the hyphosphere of arbuscular mycorrhizal fungi may thus affect mycorrhizal functions such as nutrient and water uptake carried out by the external hyphae of arbuscular mycorrhizal fungi.

An intimate relationship between arbuscular mycorrhizal fungi and plants has existed for at least 350 million years (Remy et al., 1994). This co-evolution has involved numerous interactions at the ecological, physiological and molecular levels between these organisms during the long development of the symbiosis. Today, about $95 \%$ of the world's extant species of vesicular plants that are typically mycorrizal, making this association of fundamental importance in all ecosystems (Trappe, 1987). During the intergeneric interactions, arbuscular mycorrhizal fungi are believed to enhance the phosphate nutrition of plants by scavenging the available phosphorus due to the large surface area of their hyphae, and by their high-affinity phosphate uptake mechanisms (Hayman, 1983). The role of arbuscular mycorrhizal fungi in improving plant phosphate nutrition and their interaction with other soil biota have been investigated with reference to host plant growth, but little is known about how these fungi affect the phosphorus status of soils. However, there are reports of organic acid production by arbuscular mycorrhizal fungi (Lapeyrie, 1988) that could solubilize the insoluble mineral phosphate. Production of organic acids by arbuscular mycorrhizal would certainly affect the availability of acid-labile insoluble phosphate and the whole issue of an arbuscular mycorrhizal-mediated increase in available phosphate needs re-examination. Among the mycorrhizal fungi, ectomycorrhizal fungi possess phosphate-solubilizing activity (Lapeyrie et al., 1991) and are capable of utilizing phosphate from inositol phosphates. They also possess phosphatase activity, through which they affect the release of phosphate from soil organic matter (Koide and Schreiner, 1992). In addition, arbuscular mycorrhizal fungi can exert a selective influence on soil microbial communities through a multiplication of -ketoglutarate catabolizing microorganisms (Duponnois et al., 2005). However, more research is required to specify the ecological relevance of arbuscular mycorrhizal symbiosis and their associated microbial communities. In addition, arbuscular mycorrhizal fungi can also make iron phosphates available to developing crops (Bolan et al., 1987). However, arbuscular mycorrhizal fungi in general do not colonize plant roots strongly under phosphorus-sufficient conditions (Amijee et al., 1989) and consequently the growth of certain plants has been found to be decreased by arbuscular mycorrhizal colonization in the presence of available phosphate (Son and Smith, 1995).

\section{PHOSPHATE-SOLUBILIZING MICROORGANISMS AS INOCULANTS FOR SUSTAINABLE AGRICULTURE}

The word "sustain", from the Latin sustinere (sus-, from below and tenere, to hold), to keep in existence or maintain, implies long-term support or permanence. As it pertains to agriculture, sustainable describes farming systems that are "capable" of maintaining their productivity and usefulness to society indefinitely. Such systems must be resource-conserving, socially supportive, commercially competitive and environmentally sound. Thus, the term sustainable agriculture means an integrated system of plant and animal production practices with a site-specific application that will, over the long term: satisfy human food and fiber needs, enhance environmental quality and sustain the economic viability of farm operations. It is achieved through management strategies, which help the producer select hybrids and varieties, soil-conserving cultural practices, soil fertility programs and pest management programs. The goal of sustainable agriculture is, hence, to minimize adverse impacts to the immediate and off-farm environments while providing a sustained level of production and profit. However, the most important constraint limiting crop yields in developing nations worldwide, and especially among resource-poor farmers, is soil fertility. Unless the soil fertility is restored in these areas, farmers can gain little benefit from the use of improved varieties and more productive cultural practices. Soil fertility can be restored effectively through the concept of integrated soil fertility management (ISFM), encompassing a strategy for nutrient management based on natural resource conservation, biological nitrogen fixation and increased efficiency of the inputs. In general, crop yields could be improved by enhancing the phosphate availability through the application of phosphatic fertilizers. However, the global energy crisis and dwindling resources have increased the cost of chemical fertilizers and this trend is expected to continue. Increasing the level of food production without affecting the cost-benefit ratio is thus a challenging task ahead of scientists worldwide. Agronomists are therefore looking vigorously for an alternative source of phosphatic fertilizer to supplement, or to replace in some cases, the chemical fertilizers to ensure competitive yields of crops. So, an alternative to chemical phosphatic fertilizers is the exploitation of various microbial processes encompassed in the soil-root interface (rhizosphere). Microorganisms that colonize the rhizosphere are actively engaged in phosphorus transformation in soil and transport phosphate to the plants. The use of phosphate-solubilizing organisms in agronomic practices is advocated for several reasons. For example, they improve soil fertility through their sustained activities in the soil, increase plant growth and crop yield through increased nutrient availability, do not cause environmental pollution, improve soil heath and conditioning, protect plants against some soilborne pathogens and involve low-cost technology for their production with a high cost-benefit ratio.

For agronomic purposes, phosphorus is second only to nitrogen as the most limiting element for plant growth. Phosphorus promotes nitrogen fixation in legume crops and is essential for photosynthesis, energy and sugar production (Saber et al., 2005). Microbial involvement in the solubilization of inorganic phosphate is well documented. Most of the studies on phosphate solubilization were, however, centered on the isolation of the microorganisms from the rhizospheric soil and then evaluating their phosphate-solubilizing activity under in vitro conditions. The investigations into solubilization of phosphorus under field conditions and its uptake by plants were, however, started later. In this context, the beneficial effects of inoculation 
with PSM for many crop plants have been described (Zaidi and Khan, 2005; Zaidi et al., 2003, 2004). Nitrogen-fixing bacteria are, perhaps, the most promising group of PSM on account of their ability to fix nitrogen symbiotically (legumes) or asymbiotically (non-legumes), together with the ability of some strains to solubilize inorganic phosphatic compounds. Several publications have demonstrated that phosphate-solubilizing strains of Rhizobium, Bradyrhizobium and Azotobacter increase growth and phosphorus content in both non-leguminous and leguminous plants. An alternative approach for the use of PSM as microbial inoculants is either the use of mixed cultures or co-inoculation with other microorganisms. In this regard, some results suggest a synergistic interaction between arbuscular mycorrhizal fungi and phosphate-solubilizing bacteria, which allows for better utilization of poorly soluble phosphatic sources. Phosphate-solubilizing bacteria have already been applied as effective inoculants in agronomic practices to raise the crop productivity. For example, in the former Soviet Union a commercial biofertilizer under the name "phosphobacterin" was first prepared using Bacillus megaterium var. phosphaticum and later on was frequently applied in East European countries and India. In the following section how PSM are applied in sustainable agriculture will be discussed.

\section{HOW ARE PHOSPHATE-SOLUBILIZING MICROORGANISMS APPLIED?}

Since the introduction of PSM inoculants, the application of PSM inoculant to the seed surface prior to sowing is traditionally the most commonly used and easiest means of inoculation. When properly applied, this method ensures that each seed receives the introduced microphos. Disadvantages include a limitation of the quantity that can adhere to the seed surface, direct contact with any seed-applied chemicals, movement of PSM away from the rooting zone and exposure to environmental stress after planting. However, the use of a sticker solution, e.g., gum arabic improves the adherence of the inoculant PSM on the seed. There are, however, certain situations where seed applications may be an ineffective means of application, e.g., with seeds dressed with pesticides incompatible with PSM. Under such circumstances, soil application may be followed. Inoculants applied to the soil have the following advantages greater population of PSM per unit area, direct contact with chemically-treated seeds is minimized, elimination of seed mixing, and apparent ability to withstand low moisture conditions better than the powder form. Thus, in accordance with these considerations, two approaches can be applied for PSM inoculation-firstly, the single culture approach (SCA), where phosphate-solubilizing organisms can be used alone, and secondly, the multiple or mixed culture approach (MCA), often called co-inoculation, where PSM are used along with other beneficial rhizosphere microorganisms

\section{FACTORS AFFECTING THE SURVIVAL OF PHOSPHATE-SOLUBILIZING MICROORGANISM INOCULANTS}

The competitiveness of a phosphate-solubilizing microorganism in natural environments will depend upon its ability to survive and multiply in soil. However, understanding of this part of the use of PSM is the most limiting factor and it is difficult, if not impossible, to predict the behavior and efficacy of the inoculated PSM in a particular location. In general, the population size or density of the artificially introduced PSM decline rapidly upon introduction into soils (Ho and Ko, 1985). The survival of the inoculant strain thus depends upon various factors, such as soil composition (Bashan et al., 1995), physiological status, temperature, $\mathrm{pH}$, moisture content (Van Elsas et al., 1991) and the presence of recombinant plasmids (Van Veen et al., 1997). The biotic factors that affect the survival of the inoculated PSM include competition, predation and root growth that provides the substrates to the microbes.

\section{CROP RESPONSE TO COMPOSITE INOCULATIONS}

The soil is a habitat for a vast, complex and interactive community of naturally occurring soil organisms, whose activities largely determine the physico-chemical properties of the soil and consequently promote the growth of the crop plants. From seed germination until a plant reaches maturity, it lives in close association with soil organisms. The association is termed rhizocoenosis (Lynch, 1983) and, hence, the rhizosphere that harbors heterogeneous microbial communities with sufficient phosphate-solubilizing abilities becomes an important soil habitat. Therefore, the focus of attention has now been shifted from plant microbe interactions to plant microbe-microbe interactions. Recently, some instances have been reported where plant growth has been markedly enhanced using two or three member associations of rhizospheric organisms and such syntropic associations are of paramount agronomic utility. In the present section, an attempt is made to address and discuss the interactions of PSM with other rhizospheric microorganisms and their impact on crop yield.

\subsection{Interaction between phosphate-solubilizing and nitrogen-fixing organisms}

Nitrogen and phosphorus are the two major plant nutrients, and combined inoculation of nitrogen fixers and PSM may benefit the plants better than either group of organisms alone. Interaction studies have been done both in vitro and in vivo (Sarojini et al., 1989). Phosphate solubilization was observed by mixed cultures (e.g., Pseudomonas striata, Bradyrhizobium sp. and Mesorhizobium ciceri), suggesting that they could be used as mixed microbial inoculant (Fig. 2). Further, no antagonistic behavior of one organism towards another was noted (Fig. 3). Thus, mixed cultures or co-inoculation with other microorganisms are generally preferred over single inoculation treatments. In this context, nitrogen fixers and PSM when inoculated together colonized the rhizosphere and enhanced the growth of legumes by providing them with nitrogen and phosphate, respectively (Gull et al., 2004). Nitrogen-fixing organisms not only provide nitrogen to the plants, but also improve the nitrogen status of soil, alone or in combination with PSM. Accordingly, the application of phosphate-solubilizing bacteria (Pseudomonas striata) and nodule bacteria gave significantly higher yield in greengram (Khan et al., 1997) and chickpea 


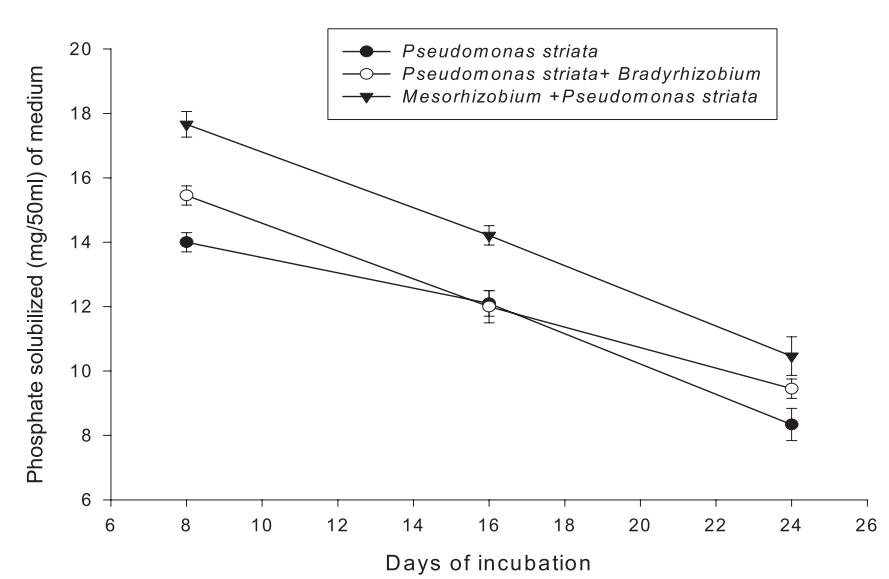

Figure 2. In vitro solubilization of tricalcium phosphate by Pseudomonas striata alone and as influenced by Bradyrhizobium sp. (vigna) and Mesorhizobium ciceri in liquid Pikovskaya medium at different incubation days.

(Algawadi and Gaur, 1988) than obtained by the use of Rhizobium alone. Furthermore, Rhizobium and phosphate-solubilizing fungi (Aspergillus awamori), when used as seed inoculant, increased the grain yield of chickpea under field conditions (Dudeja et al., 1981). Similarly, the effect of interactions between three phosphate-solubilizing fungi: namely, Aspergillus niger, A. fumigatus and Penicillium pinophilum and nitrogen-fixing Rhizobium leguminosarum biovar viciae showed significantly greater positive effects on growth, nutrient uptake (nitrogen and phosphorus) and consequently, the yield of Vicia faba under field conditions (Mehana and Wahid, 2002). Longterm (10-year) trials using phosphate-solubilizing bacteria and nitrogen-fixing organisms enhanced the seed production in soybean crops and were found to be more effective compared with superphosphate alone (Dubey, 2001). In a similar study, single or combined inoculation with PSM and nitrogen fixers had a positive effect on the yield and nutrient uptake of cereals and legume crops (Sarojini and Mathur, 1990; Kumar et al., 2001; Whitelaw, 2000).

A beneficial effect of phosphate solubilizer alone and in combination with nitrogen fixer on cotton in fields (Kundu and Gaur, 1980) and wheat (Zaidi and Khan, 2005) has been reported. Co-inoculation studies using Rhizobium and phosphate-solubilizing bacteria have been carried out by many researchers (Kucey, 1987; Downey and Van Kussel, 1990). Similar results were obtained for French bean (phaseolus vrisulga) when inoculated with Agrobacterium, a phosphate solubilizer. In contrast, beans grown in autoclaved soil inoculated with phosphate-solubilizing Penicillum baliji, and R.. phaseoli showed no significant increase in dry matter or total uptake of phosphate (Kucey, 1987). Further, a decrease in total nitrogen fixation in field peas due to dual inoculation of Penicillium bilaji and Rhizobium leguminosarum has also been reported (Downey and Van Kussel, 1990). It was suggested that the adverse effect of Penicillium bilaji on nitrogen fixation might be explained by the mode of action of the fungus. The phosphate-releasing fungi produce more organic acids (Venkateswarlu et al., 1984), which enhance the solubilization of phosphate. However, most rhizobia prefer neutral or alkaline

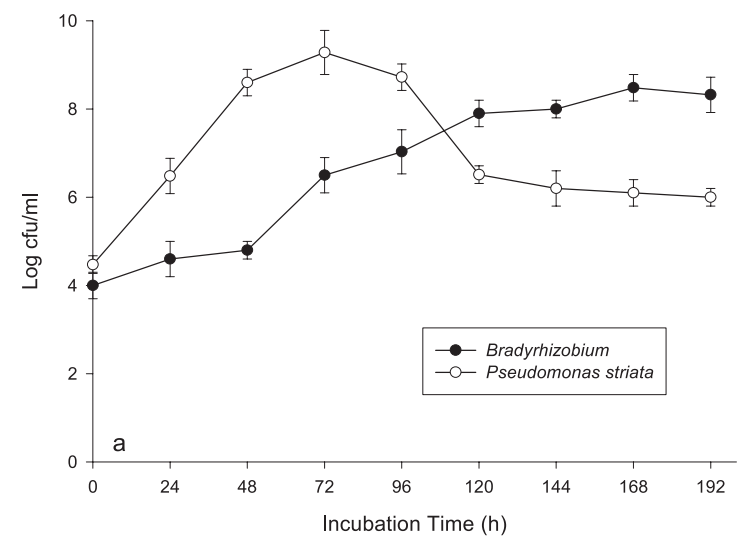

(a)

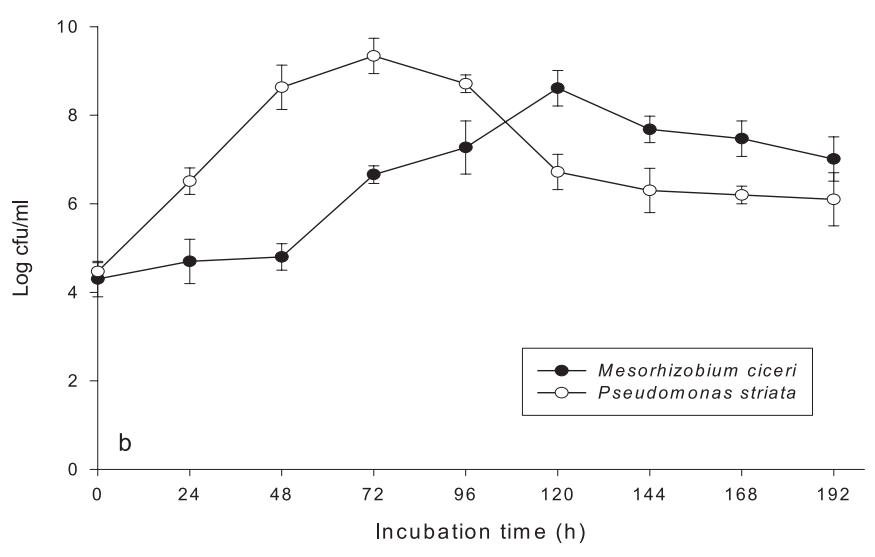

(b)

Figure 3. Synergistic relationship between Bradyrhizobium sp. (vigna) and Pseudomonas striata (a) and Mesorhizobium ciceri and Pseudomonas striata (b) in liquid Pikovskaya medium.

conditions during nodulation. These results suggest that before carrying out in vitro studies, the compatibility between the two associates must be checked in vivo.

Combined inoculation of Rhizobium and phosphate-solubilizing Pseudomonas striata or Bacillus polymyxa with or without added fertilizers on chickpea yield and nutrient content was studied under greenhouse conditions. Rhizobium inoculation alone increased nodulation and nitrogenase activity, whereas the phosphate-solubilizing organism increased the available phosphorus content of the soil. The combined inoculation increased nodulation and available phosphate of the soil, as well as the dry matter of the plants, grain yield and phosphorus and nitrogen uptake by the plants. The inoculation effects, however, were more pronounced in the presence of added fertilizers (Algawadi and Gaur, 1988). In a pot experiment, lentil seeds were inoculated with Rhizobium leguminosarum along with increasing doses $(50,100,200$ and $400 \mathrm{~kg} /$ feddan, 1 feddan = $0.42 \mathrm{ha}$ ) of rock phosphate with or without a 1:1 mixture of elemental sulfur and rock phosphate in the presence or absence of phosphate-solubilizing bacteria. Plant dry weight and nitrogen, 


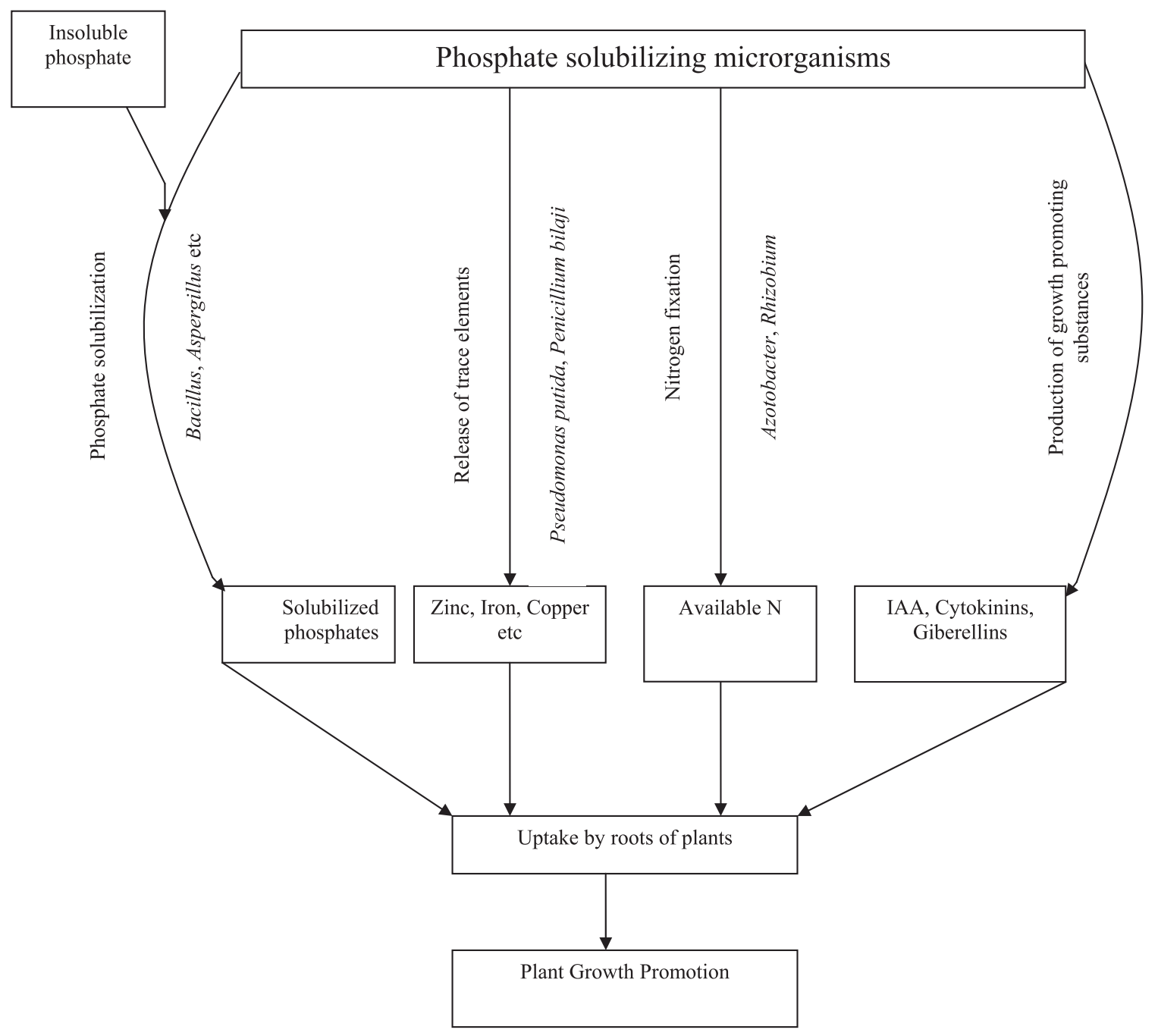

Figure 4. Mechanism of plant growth promotion by phosphate solubilizing microorganisms.

phosphorus, iron, zinc, manganese and copper uptake increased with rock phosphate, sulfur and phosphate-solubilizing bacteria compared with untreated control. Dry matter yield and nutrient uptake was slightly higher with sulfur application (Saber and Kabesh, 1990). A combination of Azotobacter chroococcum GA-1 and GA-3 with Penicillium HF-4 and HF-5 and Aspergillus GF-1 and GF-2 increased radicle and plumule length, but the remaining culture combinations decreased radicle/plumule length. A significant increase in mungbean yield and groundnut yield was observed with the inoculation of Rhizobium spp. and phosphate-solubilizing bacteria along with phosphatic fertilizers (Khan et al., 1997, 1998). Moreover, the microbes that are involved in phosphate solubilization, as well as carrying out better scavenging of soluble phosphate, can enhance plant growth by improving the efficiency of biological nitrogen fixation, accelerating the availability of other trace elements, and by production of phytohormones (Fig. 4). Accordingly, increase in yield of various legumes has been observed following seed or soil inoculation with nitrogen-fixing organisms and PSM (Zaidi, 1999; Perveen et al., 2002) or PSM and arbuscular mycorrhizal fungus (Mukherjee and Rai, 2000). It has further been suggested that about $50 \%$ of phosphatic fertilizer requirement could be saved by the combined inoculation of Rhizobium strain Tt 9 with Bacillus megaterium var. phosphaticum in groundnut. Rhizobium strain Tt 9 along with phosphobacteria at a $75 \%$ phosphate level recorded higher nodule number, root length and shoot length and increased pod yield than dual inoculation at a $100 \%$ phosphorus level in groundnut (Natarajan and Subramanian, 1995). However, no significant increase in phosphate contents in pigeonpea plants inoculated with Rhizobium (CCI) with Bacillus megaterium var. phosphaticum was observed (Gunasekaran and Pandiyarajan, 1995). Similarly, about a $37 \%$ increase in the grain yield of blackgram was reported following the inoculation of Rhizobium and Bacillus megaterium (Prabakaran et al., 1996). Gaind and Gaur (1991) reported improved nodulation, available $\mathrm{P}_{2} \mathrm{O}_{5}$ 


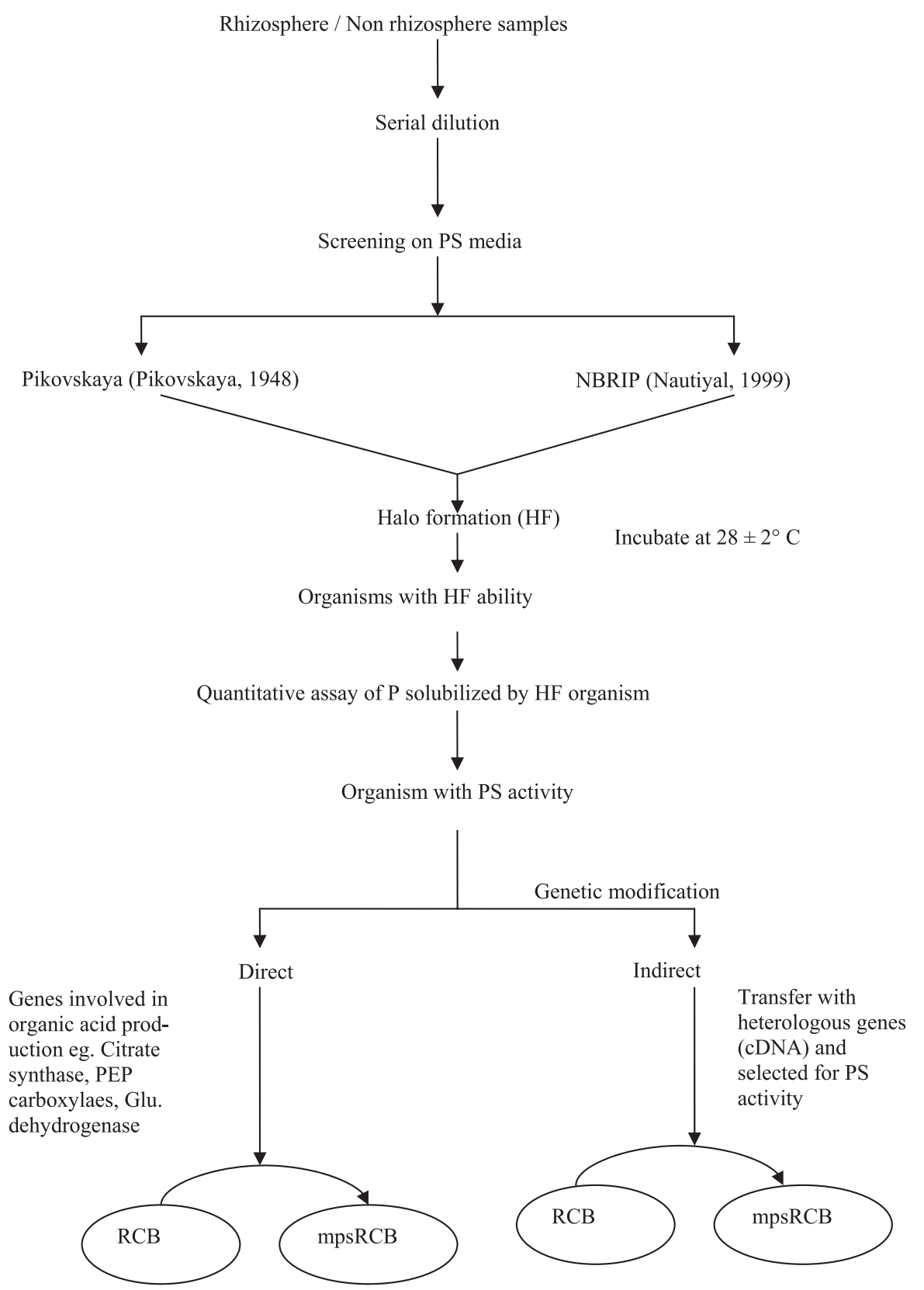

Figure 5. Selection and genetic modification of phosphate solubilizing microorganism.

content of soil, root and shoot biomass, straw and grain yield and nitrogen and phosphorus uptake by moongbean [Vigna raiata (L.) wilczek] plants upon inoculation with thermo-tolerant species of phosphate-solubilizing Bacillus subtilus, $B$. circulans and Aspergillus niger. Dubey and Billore (1992) showed an increase in yields of legumes after inoculation with rock phosphate and the phosphate-solubilizing bacteria, Bacillus megaterium and Pseudomonas striata, and the phosphatesolubilizing fungus Aspergillus awamori and suggested using low-grade rock phosphate for both neutral and alkaline soils with phosphate-solubilizing inoculants. The effect of inocula- tion with the phosphate-solubilizing bacterium Bacillus firmus, irrigation schedules and phosphorus levels on lentil (Lens esculentus) and black gram (Vigna mungo) resulted in significantly greater seed yield in field trials during the winter seasons (Tomar et al., 1993). While, in a number of field trials carried out during 1991 and 1992 using soybean as a test crop under rainfed conditions on vertisol, a significantly greater yield and phosphorus content in the plants were observed when seeds were bacterized with Pseudomonas striata and rock phosphate than compared with single superphosphate application (Dubey, 1996). 


\subsection{Symbioses between phosphate-solubilizing microorganisms and arbuscular mycorrhizal fungi}

Mycorrhizal fungi are ubiquitous soil inhabitants and form symbioses with terrestrial plants (Jeffries, 1987). However, in association with nitrogen fixers, arbuscular mycorrhizal fungi increase nitrogen and phosphatic nutrients of plants, especially in phosphorus-deficient soil (Cruz et al., 1988). In addition, PSM interact well with arbuscular mycorrhizal fungi in phosphorus-deficient soils or soils with rock phosphate (Poi et al., 1989). PSM can release some phosphatic ions from otherwise sparingly soluble phosphorus sources (Barea et al., 1983), which are tapped and translocated by the arbuscular mycorrhizal fungal hyphae to the plant (Azcon-Aguilar et al., 1986). Moreover, the PSM survive longer around mycorrhizal roots compared with non-mycorrhizal roots and act synergistically with the arbuscular mycorrhizal fungus, leading to increased plant growth, especially where rock phosphate is applied to soil (Singh, 1990). Simultaneous dual inoculation of arbuscular mycorrhizal fungi and PSM has been shown to stimulate plant growth more than inoculation of either microorganism alone in certain situations when the soil is phosphorus-deficient (Piccini and Azcon, 1987). The simplest interpretation of this fact is that the mycorrhizal endophyte could be stimulated in quantity, efficiency and longevity. The main effect of this mycorrhiza in improving plant growth is through improved uptake of nutrients, especially phosphorus, due to the exploration by the external hyphae of the soil beyond the root-hair zone where phosphorus is depleted. Besides, root exudation and plasticity might change by PSM inoculation, which could also affect arbuscular mycorrhizal development. The arbuscular mycorrhizal fungi also produce plant hormones and increase the activity of nitrogen-fixing organisms in the root zone (Bagyaraj, 1984). However, a more thorough understanding of interactions between soil microorganisms is needed for an optimal utilization of these interactions with respect to the growth and development of plants. When centrosema macrocarpum plants were inoculated with Rhizobium strains and the arbuscular mycorrhizal fungi Glomus manihotis or Acaulospora longula, a significantly greater dry matter production, mineral absorption, nodulation and infection by arbuscular mycorrhizal fungi was recorded (Satizabal and Saif, 1987). However, a small amount of nitrogen fertilizer was suggested for application at the time of sowing. The dual inoculation of Azotobacter chroococcum and Glomus fasciculatum enhanced root infection of arbuscular mycorrhizal fungi, stimulated plant growth, and increased nitrogen, phosphorus and zinc contents in maize and wheat (Elgala et al., 1995). Similarly, a significant increase in dry matter yield of wheat plants following dual inoculation of rock phosphate-solubilizing fungi (Aspergillus niger and Penicillium citrinum) and Glomus constrictum was recorded (Omar, 1998). Combined inoculation of Rhizobium and Glomus etunicatum and application of rock phosphate or PSM and arbuscular mycorrhizal fungus gave the greatest yield and had variable effects on nodulation in clovers (Leopold and Hofner, 1991), mungbean (Zaidi et al., 2004), cowpea (Thiagarajan et al., 1992) and chickpea (Poi et al., 1989). Experiments have revealed that the establishment of arbuscular mycorrhizal fungus on the root system can alter the rhizospheric microbial populations (Ames et al., 1984), which in turn affects the competitive interaction between introduced and native rhizobia for nodulation sites.

\subsection{Tripartite symbioses between nitrogen fixers, phosphate solubilizers and arbuscular mycorrhizal fungi}

In an earlier section the inoculation effects of single and dual cultures of nitrogen fixers and PSM on crop plants were discussed. However, very few reports are available on the effect of combined inoculation of crop plants with nitrogen fixers and PSM in the presence of arbuscular mycorrhizal fungus. During the inter-generic interaction, nitrogen-fixing microorganisms provide nitrogen to the plants and consequently improve the nitrogen status of the soil, while PSM enhance plant growth by providing it with phosphates. Where nitrogen and phosphorus are limiting, arbuscular mycorrhizal fungi may improve phosphate uptake for plants; the higher phosphorus concentration in the plant benefits the nitrogen fixers and the functioning of its nitrogenase, leading to increased nitrogen fixation, which in turn promotes root and mycorrhizal development. In a study, Singh and Singh (1993) investigated the associative effect of Bradyrhizobium japonicum, arbuscular mycorrhizal fungus and phosphate-solubilizing microbes on soybean in a mollisol. Inoculation with the endophyte alone resulted in $70 \%$ root colonization. Addition of rock phosphates or inoculation with phosphate-solubilizing bacteria except Bacillus polymyxa stimulated root infection of native as well as introduced arbuscular mycorrhizal endophytes. Application of rock phosphate with triple inoculation significantly increased grain yield, nodulation, nitrogen uptake and available soil phosphate. Further, Bethlenfalvay (1994) demonstrated the impact of Glomus mosseae, Bacillus sp. and Rhizobium sp. on plant growth and soil aggregation under Pisum sativum cultivation. Complex interaction was found among the three microorganisms, which in turn dramatically promoted plant growth and soil aggregation. It is evident from the earlier studies that a positive interaction exists between root colonization, phosphorus uptake and growth promotion, as observed by a few researchers (Zaidi et al., 2003; Zaidi and Khan, 2005). Inoculation of Rhizobium, Bacillus polymyxa and Glomus faciculatum resulted in significantly greater dry matter production and $\mathrm{PO}_{4}^{-}$uptake as compared with single or double inoculation (Poi et al., 1989). However, no significant response of soybean to dual inoculation was observed (Kloepper et al., 1980).

\section{WHY DO PHOSPHATE-SOLUBILIZING MICROORGANISM INOCULATIONS FAIL?}

Doubts have been raised about the ability of PSM to liberate phosphate under soil conditions (Tinker, 1980). Growth promotion and crop yields following superphosphate supplementation, despite the abundance of PSM in the rhizosphere and bulk soils, raises important issues on the variations in the effectiveness of PSM inoculations. Why is phosphorus limited for plants when PSM are abundant in soils? Many reasons have been proposed to account for the variations in the effectiveness of PSM inoculations on plant growth and crop yields (Kucey et al., 1989): 1 survival and colonization of inoculated PSM in 
the rhizosphere; 2 competition with native microorganisms; 3 nature and properties of soils and plant varieties; 4 insufficient nutrients in the rhizosphere to produce enough organic acids to solubilize phosphorus, and 5 inability of PSM to solubilize soil phosphorus. It has been shown that at least two PSM showing phosphate solubilization in laboratory conditions could not release phosphate from alkaline vertisols even when supplemented with other nutrients (Gyaneshwar et al., 1998). Similarly, no soluble phosphate was liberated when non-sterilized bulk and rhizospheric soil samples were supplemented with carbon and nitrogen. The ability of the PSM to release phosphate from mineral phosphorus was significantly decreased, possibly due to the high buffering capacity of the soils, coupled with the PSM's inability to secrete high concentrations of organic acids.

Moreover, despite the promising results, PSM-based biofertilizers have not got widespread application in agriculture, mainly because of the variable response of plant species or genotypes to inoculation, depending on the bacterial strain used. The differential rhizosphere effect of crops in harboring a target phosphate-solubilizing bacterial strain or even the modulation of the bacterial phosphate-solubilizing capacity by specific root exudates may account for the observed differences. On the other hand, good competitive ability and high saprophytic competence are the major factors determining the success of a bacterial strain as an inoculant. Therefore, studies to find out the competitiveness and persistence of specific microbial populations in complex environments, such as the rhizosphere, should be addressed in order to obtain efficient inoculants. In this regard, efforts in order to obtain appropriate formulations of microbial inoculants, which protect the inoculant organism against environmental stresses and at the same time enhance and prolong its activity, may help in promoting the use of such beneficial bacteria in sustainable agriculture.

\section{APPLICATION OF GENETIC ENGINEERING IN DEVELOPING SUPERPHOSPHATE- SOLUBILIZING MICROBIAL INOCULANTS}

The performance of PSM inoculants depends heavily on their ability to colonize a particular rhizosphere habitat. The study of colonization of phosphate solubilizers provides useful information to solve the deficiency of phosphorus of soils. Plate counting and most-probable-number techniques have been used for the study of PSM communities in the rhizosphere. However, in general, less than $1 \%$ of the microorganisms in the environment can usually be cultured by standard techniques because these techniques fail to reproduce in artificial media. The niches of many microorganisms are found in high-diversity environments such as the rhizosphere. However, using strainspecific DNA probes we can decipher a considerable number of heterogenous groups of microorganisms in the rhizosphere (Cooper et al., 1998; Frederic et al., 2000). Thus, the recent development of molecular biology techniques, which do not rely on cultivation methods, allows microbial ecologists to reveal inhabitants of natural microbial communities, which have not yet been cultured (Hugenholtz et al., 1998; Snaidr et al., 1998). As a result, these techniques are now widely applied to characterizing microbial community structures in different environments (Holben et al., 1998; Nozawa et al., 1998).

Two of these techniques, cloning and sequencing, allow us to determine which microorganisms are present in the community, but they are time-consuming. Hybridization and probing are faster, but require a sufficient knowledge of the community to choose the appropriate target sequence (Amann, 1995). However, other molecular biology techniques such as amplified ribosomal DNA restriction analysis (ARDRA) or ribosomal intergenic spacer analysis (RISA) can be applied to study the PSM colonization or community structure. Even faster than hybridization and probing, ARDRA and RISA have been used in the analysis of mixed bacterial populations from different environments (Moyer et al., 1994; Martinez-Murcia et al., 1995). Although ARDRA gives little or no information about the type of microorganisms present in the sample, it can be used for a quick assessment of genotypic changes in the community over time, or to compare communities subject to different environmental conditions. In comparison, RISA is a method of microbial community analysis that provides a means of comparing differing environments or treatment impacts without the bias imposed by culture-dependent approaches. In brief, RISA involves polymerase chain reaction amplification of a region of the rRNA gene operon between the small (16S) and large (23S) subunits called the intergenic spacer region (ISR). By using oligonucleotide primers targeted at conserved regions in the $16 \mathrm{~S}$ and $23 \mathrm{~S}$ genes, RISA fragments can be generated from most of the dominant bacteria in an environmental sample. While the majority of the rRNA operon serves as a structural function, portions of the $16 \mathrm{~S}-23 \mathrm{~S}$ intergenic regions can encode tRNAs, depending on the bacterial species. However, the taxonomic value of the ISR lies in the significant heterogeneity in both length and nucleotide sequence. In RISA, we thus attempt to exploit the length heterogeneity of the ISR. The use of such molecular techniques, having greater quantitative efficiency, can be extended to study the colonization and characterization of PSM inoculants under diverse environmental conditions.

Moreover, the solubilization of mineral phosphate is carried out by organic acids, either by reduction in $\mathrm{pH}$, or chelating the cations associated with phosphorus. A better understanding of the genetic basis of the release of organic acids could pave the way for transferring the mineral phosphate-solubilizing (mps) ability to various bacteria that are competent of colonizing a particular rhizosphere. Among the various factors, rhizosphere competence is a focal point that decides the success or failure of the inoculant. The rhizosphere has tremendous amounts of carbon sources that are available to the heterogeneous microbial communities in soil to produce different kinds of organic acids. In addition, the solubilized phosphates can be utilized by the plant before it gets precipitated again. Among the various organic acids, gluconic acid seems to be the major mechanism of phosphate solubilization by Gram-negative bacteria (Goldstein et al., 1993; Kim et al., 1998). Gluconic acid is produced by the oxidative metabolism of glucose by glucose dehydrogenase $(\mathrm{GDH})$, which requires pyrroloquinoline quinine (PQQ) as a cofactor. Thus, the genes involved in the biosynthesis/transport of PQQ can be cloned from various bacteria and transferred to other bacteria (Babu-Khan et al., 1995). For instance, the rhizosphere competent bacteria (RCB) such as Rhizobium possess apo-GDH; it would be interesting to transfer the genes involved 
in PQQ biosynthesis to Rhizobium to make an effective and better PSM. The resulting Rhizobium strains will thus have phosphate-solubilizing (PS) activity in addition to their natural nitrogen-fixing ability. Another important rhizosphere competent bacterium (Pseudomonas spp.) can form gluconic acid through the oxidative glucose metabolism and overexpression of PQQ biosynthesis and GDH genes could also make it a better PSM (Fig. 5). The alternative approach is to screen the mineral phosphate-solubilizing (mps) genes directly in the target bacteria by over/underexpression of genes, followed by the selection of transformants with mineral phosphate-solubilizing ability. Such an approach has been used to obtain mineral phosphate-solubilizing genes from Synechosystis PCC 6803 in E. coli (Gyaneshwar, 1998). However, it remains to be seen if this will also be effective in other bacteria. Genetic engineering could also help in increasing the survival of the inoculant strains by incorporating the abilities to utilize certain nutrients better than the rest of the microbial populations (Glick and Bashan, 1997). Also, genes for utilization of salicylate were transferred to a growth-promoting bacteria and the recombinant bacterium was able to survive and enhance plant growth better than the wild type (Colbert et al., 1993).

\section{CONCLUSION}

The phosphatic fertilizer in current use requires a greater input that cannot be afforded by the farmers of the developing nations. Microbiologists and soil scientists thus have a responsibility to society to find ways and means of making phosphorus available to crops, an economically efficient substitute for fertilization of crops. Since most soils are deficient in plant-available phosphorus and chemical fertilizers are not cost-effective, there is interest in using rhizosphere competent bacteria (RCB) or soil microorganisms endowed with phosphate-solubilizing ability as inoculants to mobilize phosphate from poorly available sources in soil. Although potential clearly exists for developing such inoculants, their widespread application remains limited by a poor understanding of microbial ecology and population dynamics in soil, and by inconsistent performance over a range of environments. Furthermore, promotion of growth of agronomically important plants, as a consequence of microbial inoculation, may not necessarily be associated with characteristics such as phosphate solubilization, which are manifest under laboratory conditions. Further, in order to ensure food security in developing countries, there is an urgent need for the sustainable intensification of agricultural production systems towards supporting productivity grains and income generation. In this context, novel, genetically-modified soil and regionspecific PSM and technologies for their ultimate transfer to the fields have to be developed, pilot-tested and transferred to farmers in a relatively short time.

\section{REFERENCES}

Abd-Alla M.H. (1994) Solubilization of rock phosphates by Rhizobium and Bradyrhizobium, Folia Microbiol. 39, 53-56.

Ahmed S. (1995) Agriculture - Fertilizer Interface In Asia Issues of Growth and sustainability, Oxford and IBH publishing Co, New Delhi.
Algawadi A.R., Gaur A.C. (1988) Associative effect of Rhizobium and phosphate solubilizing bacteria on the yield and nutrient uptake of chickpea, Plant Soil 105, 241-246.

Amann R.I. (1995) Fluorescently labeled rRNA targeted nucleotide probes in the study of microbial ecology, Microbial. Ecol. 4, 543554.

Ames R.N., Reid C.P.P., Ingham E.R. (1984) Rhizosphere bacterial population responses to root colonization by a vesicular arbuscular mycorrhizal fungus, New Phytol. 96, 555-563.

Amijee F., Tinker P.B., Stribley D.P. (1989) Effect of phosphorus on the morphology of vesicular-arbuscular mycorrhizal root system of leek (Allium porrum L.), Plant Soil 119, 334-336.

Antunes V., Cardoso E.J.B.E. (1991) Growth and nutrient status of citrus plants as influenced by mycorrhiza and phosphorus application, Plant Soil 131, 11-19.

Asea P.E.A., Kucey R.M.N., Stewart J.W.B. (1988) Inorganic Phosphate solubilization by two Penicillium species in solution culture and soil, Soil Biol. Biochem. 20, 459-464.

Azaizeh H.A., Marshner A., Romheld V., Wittenmayer L. (1995) Effects of a vesicular- arbuscular mycorrhizal fungus and other soil microorganisms on growth, mineral nutrient acquisition and root exudation of soil grown maize plants, Mycorrhiza 5, 321-327.

Azcon-Aguilar C., Diaz-Rodriguez R., Barea, J.M. (1986) Effect of soil microorganisms on spore germination and growth on the vesicular arbuscular mycorrhizal fungus (Glomus moseae), Trans. Brit. Mycol. Soc. 86, 337-340.

Babu-Khan S., Yeo T.C., Martin W.I., Duron M.R., Rogers R.D., Goldstein A.H. (1995) Cloning of a mineral phosphate solubilizing gene from Pseudomonas cepacia, Appl. Environ. Microbiol. 61, 972-978.

Bagyaraj D.J. (1984). Biological interaction with VA mycorrhizal fungi, in: Powell C.L., Bagyaraj D.J. (Eds.), VA mycorrhiza, CRC Press, Boca Raton, pp. 131-153.

Banik S., Dey B.K. (1982) Available phosphate content of an alluvial soil as influenced by inoculation of some isolated phosphate solubilizing microorganisms, Plant Soil 69, 353-364.

Banik S., Dey B.K. (1983) Phosphate solubilizing potentiality of the microorganisms capable of utilizing aluminium phosphate as a sole phosphate source, Zbl. Microbiol. 138, 17-23.

Barber S.A. (1984) Soil nutrient bioavailability, John Wiley, New York, USA.

Barea J.M., Azcon R., Azcon-Aguilar C. (1983) Interaction between phosphate solubilizing bacteria and VA mycorrhiza to improve the utilization of rock phosphate by plants in non acidic soils, Third Inter. Congress on Phosphorus Compounds, Brussels, pp. 127-152.

Barea J.M., El-Atrach F., Azcon R. (1991) The role of VA mycorrhizas in improving plant $\mathrm{N}$ acquisition from soil as assessed with ${ }^{15} \mathrm{~N}$. The use of stable isotopes in plant nutrition, in: Fitton C. (Ed.), Soil Fertility and Enviornmental Studies, Joint AIEA, FAO, Division, Vienna, pp. 677-808.

Bar-Yosef B., Rogers R.D., Wolfram J.H., Richman E. (1999) Pseudomonas cepacia mediated rock phosphate solubilization in kaolinite and montmorillonite suspensions, Soil Sci. Soc. Am. J. 63, $1703-1708$

Bashan Y., Puente M.E., Rodriquea M.N., Toledo G., Holguin G., Ferrera-Cerrato R., Pedrin S. (1995) Survival of Azorhizobium brasilense in the bulk soil and rhizosphere of 23 soil types, Appl. Environ. Microbiol. 61, 1938-1945.

Bethlenfalvay G.J. (1994) Sustainability and rhizoorganisms in an ecosystem, Sociedad Maxicana de la Ciencia del Suelo. 4, 9-10.

Bolan N.S. (1991) A critical review on the role of mycorrhizal fungi in the uptake of phosphorus by plant, Plant Soil 134, 189-207.

Bolan N.S., Robson A.D., Barrow N.I. (1987) Effect of vesicular arbuscular mycorrhiza on availability of iron phosphates to plants, Plant Soil 99, 401-410. 
Burgstaller W., Straser H., Shinner F. (1992) Solubilization of zinc oxide from filter dust with Penicillium simplicissimum: bioreactor, leaching and stoichiometry, Environ. Sci. Technol. 26, 340-346.

Burkert B., Robson A. (1994) Zn uptake in subterranean clover (Trifolium subterraneum 1.) by three vesicular-arbuscular mycorrhizal fungi in a root free sandy soil, Soil Biol. Biochem. 26, 1117-1124.

Chabot R., Anton H., Cescas M.P. (1996): Growth promotion of maize and lettuce by phosphate solubilizing Rhizobium leguminosarum biovar phaseoli, Plant Soil 184, 311-321.

Colbert S.F., Hendson M., Ferri M., Schroth M.N. (1993) Enhanced growth and activity of a biocontrol bacterium genetically engineered to utilize salicylate, Appl. Microbiol. 59, 2071-2076.

Cooper J.E., Bjourson A.J., Streit W., Werner D. (1998) Isolation of unique nucleic acid sequence from rhizobia by genomic subtraction: Application in microbial ecology and symbiotic gene analysis, Plant Soil 204, 47-55.

Cruz R.E. de la., Manalo M.Q., Aggangan N.S., Tambalo J.D. (1988) Growth of three legume trees inoculated with VA mycorrhizal fungi and Rhizobium, Plant Soil 108, 111-115.

Cunningham J.E., Kuiack C. (1992) production of citric and oxalic acids and solubilization of calcium phosphate by Penicillium bilaji, Appl. Environ. Microbiol. 58, 1451-1458.

Downey J., Van Kessel C. (1990) Dual inoculation of Pisum sativum with Rhizobium leguminosarum and Penicillium bilaji, Biol. Fert. Soils 10, 194-196.

Dubey S.K. (1996) Response of soybean to rock phosphate applied with Pseudomonas striata in a typic chromustert, J. Ind. Soc. Soil Sci. $44,252-255$.

Dubey S.K., Billore S.D. (1992) Phosphate solubilizing microorganisms (PSM) as inoculant and their role in augmenting crop productivity in India, Crop Res. 5, 11.

Dudeja S.S., Khurana A.L., Kundu B.S. (1981) Effect of Rhizobium and phosphomicroorganism on yield and nutrient uptake in chickpea, Curr. Sci. 50, 503.

Dubey SK. (2001) Associative effect of nitrogen fixing and phosphate solubilizing bacteria in rainfed soybean (Glycine max) grown in vertisols, Indian J. Agric. Sci. 71, 476-479.

Duponnois R., Colombet A., Hien V., Thioulouse J. (2005) The mycorrhizal fungus Glomus intraradices and rock phosphate amendment influence plant growth and microbial activity in the rhizosphere of Acacia holosericea, Soil Biol. Biochem. 37, 1460-1468.

Duponnois R., Kisa M., Plenchette C. (2006) Phosphate solubilizing potential of the nematofungus Arthrobotrys oligospora, J. Plant Nutr. Soil Sci. 169, 280-282.

Elgala H.M., Ishac Y.Z., Abdel-Monem M., El-Ghandour I.A.I., Hang P.M., Berthelin J., Bollag J.M., Mc Gill W.B., Page A.I. (1995) Effect of single and combined inoculation with Azotobacter and VA mycorrhizal fungi on growth and nutrient content of maize and wheat plants, Environ. Impact Soil Component Interactions. 2, $109-116$.

Frederic B.G., Estefania A., Jordi B.F., Charles A.A., Dolors M.B., Manel P. (2000) Assessment of microbial community structure changes by amplified rhibosomal DNA restriction analysis (ARDRA), Int. Microbiol. 3, 103-106.

Gaume A. (2000) Low P tolerance of various maize cultivars; the contribution of the root exudation, Ph.D. dissertation, Swiss Federal institute of Technology, Zurich, Switzerland.

Gaur A.C. (1990) Phosphate solubilizing microorganisms as biofertilizers, Omega Scientific Publisher, New Delhi, p. 176.

Giand S., Gaur A.C. (1991) Thermotolerant phosphate solubilizing microorganisms and their interactions in mungbean, Plant Soil 133, 141-149.

Glick B.R., Bashan Y. (1997) Genetic manipulation of plant growth promoting bacteria to enhance biocontrol of phytopathogens, Biotechnol. Adv. 15, 353-378.
Goldstein A.H., Rogers R.D., Mead G. (1993) Mining by microbe, Bio. Technol. 11, 1250-1254.

Gupta R.R., Singal R., Shanker A., Kuhad R.C., Saxena R.K. (1994) A modified plate assay for secreening phosphate solubilizing microorganisms, J. Gen. Appl. Microbiol. 40, 255-260.

Guissou T., Bâ A.M., Guinko S., Plenchette C., Duponnois R. (2001) Mobilisation des phosphates naturels de kodijari par des jujubiers (Ziziphus mauritiana Lam.) mycorhizes dans un sol acidifié avec de la tourbe, Fruits 56, 261-269.

Gull M., Hafeez F.Y., Saleem M., Malik K.A. (2004) Phosphorus uptake and growth promotion of chickpea by co-inoculation of mineral phosphate solubilizing bacteria and a mixed rhizobial culture, Aust. J. Exp. Agr. 44, 623-628.

Gunasekaran S., Pandiyarajan P. (1995) Dual inoculation of Rhizobium and phosphobacteria with two forms of phosphorus in pigeonpea, in: Microbiology Abstracts. XXXVI. Annual conference of the Association of Microbiologists of India, Hissar, Nov. 8-10, p. 111.

Gyaneshwar P., Naresh K.G., Parekh L.J. (1998a) Effect of buffering on the phosphate solubilizing ability of microorganisms, World J. Microb. Biot. 14, 669-673.

Gyaneshwar P., Naresh Kumar G., Parekh L.J. (1998b) Cloning of mineral phosphate solubilizing genes from Synechocystis PCC 6803, Curr. Sci. India 74, 1097-1099.

Gyaneshwar P., Parekh L.J., Archana G., Podle P.S., Collins M.D., Hutson R.A., Naresh K.G. (1999) Involvement of a phosphate starvation inducible glucose dehydrogenase in soil phosphate solubilization by Enterobacter asburiae, FEMS Microbiol. Lett. 171, 223-229.

Halder A.K., Chakrabarty P.K. (1993) Solubilization of inorganic phosphate by Rhizobium., Folia Microbiol. 38, 325-330.

Halder A.K., Misra A.K., Chakrabarty P.K. (1991) Solubilization of inorganic phosphates by Bradyrhizobium, Ind. J. Exp. Biol . 29, 28-31.

Hayman D.S. (1983) The physiology of vesicular-arbuscular endomycorrhizal symbiosis, Can. J. Bot. 61, 944-963.

Hobbie S.E. (1992) Effects of plant species on nutrient cycling, Trends Ecol. Evol. 7, 336-339.

Holben W.E., Noto K., Sumino T., Suwa Y. (1998) Molecular analysis of bacterial communities in a three compartment granular activated sludge system indicates community-level control by incompatible nitrification process, Appl. Environ. Microbiol. 64, 2528-2532.

Ho W.C., Ko W.H. (1985) Effect of environmental edaphic factors, Soil Biol. Biochem. 17, 167-170.

Hoon H., Park R.D., Kim Y.W., Rim Y.S., Park K.H., Kim T.H., Such J.S., Kim K.Y. (2003) 2-ketogluconic acid production and phosphate solubilization by Enterobacter intermedium, Current Microbiol. 47, 87-92.

Hugenholtz P., Goebel B.M., Pace N.R. (1998) Impact of culture independent studies on the emerging phylogenetic view of bacterial diversity, J. Bacteriol. 180, 4765-4774.

Illmer P., Schinner F. (1992) Solubilization of inorganic phosphates by microorganisms isolated from forest soil, Soil Biol. Biochem. 24, 389-395.

Illmer P.A., Barbato A., Schinner F. (1995) Solubilization of hardly soluble $\mathrm{AlPO}_{4}$ with P-solubilizing microorganisms, Soil Biol. Biochem. 27, 260-270.

Jeffries P. (1987) Use of mycorrhizae in agriculture, CRC Crit. Rev. Biotechnol. 5, 319-357.

Johri J.K., Surange S., Nautiyal C.S. (1999) Occurrence of salt, pH and temperature tolerant phosphate solubilizing bacteria in alkaline soils, Curr. Microbiol. 39, 89-93.

Kang S.C., Ha C.G., Lee T.G., Maheshwari D.K. (2002) Solubilization of insoluble inorganic phosphates by a soil-inhabiting fungus Fomitopsis sp. PS 102, Curr. Sci. 82, 439-442. 
Khan M.S., Aamil M., Zaidi A. (1997) Associative effect of Bradyrhizobium sp. (vigna) and phosphate solubilizing bacteria on moongbean [Vigna radiata (L.) wilczek], Biojournal. 10, 101-106.

Khan M.S., Aamil M., Zaidi A. (1998) Moongbean response to inoculation with nitrogen fixing and phosphate solubilizing bacteria, in: Deshmukh A.M. (Ed.), Biofertilizers and biopesticides, Technoscience Publications, Jaipur, pp. 40-48.

Kim K.Y., Jordan D., McDonald G.A. (1997) Solubilization of hydroxyapatite by Enterobacter agglomerans and cloned Escherichia coli in culture medium, Biol. Fert. Soils 24, 347-352.

Kim K.Y., Jordan D., McDonald G.A. (1998) Enterobacter agglomerans, phosphate solubilizing bacteria and microbial activity in soil: Effect of carbon sources, Soil Biol Biochem. 30, 995-1003.

Kloepper J.W., Schroth M.N., Miller T.D. (1980) Effects of rhizosphere colonization by plant growth promoting rhizobacteria on potato plant development and yield, Phytopathol. 70, 1078-1082.

Koide T.R, Shreinner P.R. (1992) Regulation of vesicular arbuscular mycorrhizal symbiosis, Ann. Rev. Plant Physiol. Plant Mol. Biol. 43, 557-581.

Kucey R.M.N. (1983) Phosphate solubilizing bacteria and fungi in various cultivated and virgin Alberta soils, Can. J. Soil Sci. 63, 671678.

Kucey R.M.N. (1987) Increased P uptake by wheat and field beans inoculated with a phosphorus solubilizing Penicillium bilaji strain and with vesicular arbuscular mycorrhizal fungi, Appl. Environ. Micobiol. 53, 2699-2703.

Kucey R.M.N. (1988) Effect of Penicillium bilaji on the solubility and uptake of $\mathrm{P}$ and micronutrients from soil by wheat, Can. J. Soil Sci. $68,261-270$.

Kucey R.M.N., Janzen H.H., Legget M.E. (1989) Microbial mediated increases in plant available phosphorus, Adv. Agron. 42, 199-228.

Kumar V., Behl R.K., Narula N. (2001) Establishment of phosphate solubilizing strains of Azotobacter chroococcum in the rhizosphere and their effect on wheat cultivars under greenhouse conditions, Microbiol. Res. 156, 87-93.

Kundu B.S., Gaur A.C. (1980) Effect of nitrogen fixing and phosphate solubilizing microorganism as single and composite inoculants on cotton, Ind. J. Microbiol. 20, 225-229.

Kundu B.S., Gaur A.C. (1981) Effect of single and composite cultures on rock phosphate solubilization, Haryana Agric. Univ. J. Res. 11, $559-562$.

Lapeyrie F., Ranger J., Varelles D. (1991) Phosphate solubilizing activity of ectomycorhhizal fungi in vitro, Can. J. Bot. 69, 342-346.

Lapeyrie F. (1988) Oxalate synthesis from soil bicarbonate by the mycorrhizal fungus Paxillus involutus, Plant Soil 110, 3-8.

Leisinger K.M. (1999) Biotechnology and food security, Curr. Sci. India 76, 488-500.

Leopold H., Hofner W. (1991) Improvement of clover yield and quality by inoculation with VAM fungi and Rhizobium bacteria, Angew. Bot. 65, 23-33.

Lindsay W.L., Vlek P.L.G., Chien S.H. (1989) Phosphate minerals, in: Dixon J.B., Weed S.B., Soil environment, 2nd ed., Soil Sci. Soc. America, Madison, pp. 1089-1130.

Lynch J.M. (1983). Soil Biotechnology: Microbiological factors in crop productivity, Blackwell, Scientific Publications, Oxford.

Maliha R., Samina K., Najma A., Sadia A., Farooq L. (2004) Organic acids production and phosphate solubilization by phosphate solubilizing microorganisms under in vitro conditions, Pakistan J. Biol. Sci. 7, 187-196.

Marshner P., Crowley D.E., Higashi M. (1997) Root exudation and physiological status of a root colonizing fluorescent Pseudomonad in mycorrhizal and non-mycorrhizal pepper (Capsicum annum L.), Plant Soil 189, 11-20.
Martinez-Murcia A.J., Acinas S.G., Rodriguez-Valera F. (1995) Evaluation of prokaryotic diversity by restrictase digestion of 16S rDNA directly amplified from hipersaline environments, FEMS Microbiol. Ecol. 17, 247-256.

Mehana T.A., Wahid O.A.A. (2002) Associative effect of phosphate dissolving fungi, Rhizobium and phosphate fertilizer on some soil properties, yield components and the phosphorus and nitrogen concentration and uptake by Vicia faba L. under field conditions, Pakistan J. Biol. Sci. 5, 1226-1231.

Motsara M.R., Bhattacharyya P.B., Srivastava B. (1995) Biofertilizerstheir description and characteristics, in: Biofertilizer Technology, Marketing and Usage, A sourcebook- cum-Glossary, Fertilizer development and consultation organisation 204-204, A Bhanot Corner, 1-2 Pamposh Enclave, New Delhi, 110048, India, pp. 9-18.

Moyer C.L., Dobbs F.C., Karl D.M. (1994) Estimation of diversity and community structure through restriction fragment length polymorphism distribution analysis of bacterial $16 \mathrm{~S} \mathrm{r}$ RNA genes from a microbial mat at an active, hydrothermal vent system, Loithi Seamount, Hawaii, Appl. Environ. Microb. 60, 871-879.

Mukherjee P.K., Rai R.K. (2000) Effect of vesicular arbuscular mycorrhizae and phosphate solubilizing bacteria on growth, yield and phosphorus uptake by wheat (Triticum aestivum) and chickpea (Cicer arietinum), Indian J. Agron. 45, 602-607.

Nahas E. (1996) Factors determining rock phosphate solubilization by microorganism isolated from soil, World J. Microb. Biot. 12, 1823.

Narula N., Kumar V., Behl R.K., Duebel A.A., Gransee A., Merbach W. (2000) Effect of P solubilizing Azotobacter chroococcum on N, P, $\mathrm{K}$ uptake in Presponsive wheat genotypes grown under green house conditions, J. Plant Nutr. Soil Sci. 163, 393-398.

Nautiyal C.S. (1999) An efficient microbiological growth medium for screening of phosphate solubilizing microorganisms, FEMS Microbiol. Lett. 170, 265-270.

Norrish K., Rosser H. (1983) Mineral phosphate, in: Soils, an Australian viewpoint, Academic press, Melbourne, CSIRO/London, UK, Australia, pp. 335-361.

Natarajan T., Subrammanian P. (1995) Response of phosphobacteria along with Rhizobium at two levels of phosphorus on groundnut. in: Microbiology Abstracts, XXXVI Annual Conference of the Association of Microbiologists of India, Hissar, Nov. 8-10, p. 111.

Nozawa M., Hu. H.Y., Fujie K., Tanaka H., Urano K. (1998) Quantitative detection of Enterobacter cloacae strai HO-I In bioreactor for chromate wastewater treatment using polymerase chain reaction (PCR), Water Res. 32, 3472-3476.

Omar S.A. (1998) The role of rock phosphate solubilizing fungi and vesicular arbuscular mycorrhiza (VAM) in growth of wheat plants fertilized with rock phosphate, World J. Microb. Biot. 14, 211-219.

Ozanne P.G. (1980) Phosphate nutrition of plants - general treatise. The role of phosphorus in agriculture, in: Khasawneh F.E., sample E.C., Kamprath E.J. (Eds.), American Soc. Agron. Crop Sci. Soc. America, Soil Sci. Soc. America, Madison, WI, USA, pp. 559-589.

Parks E.J., Olson G.J., Brinckman F.E., Baldi F. (1990) Characterization by high performance liquid chromatography (HPLC) of the solubilization of phosphorus in iron ore by a fungus, J. Ind. Microbiol. Biot. 5, 183-189.

Perveen S., Khan M.S., Zaidi A. (2002) Effect of rhizospheric microorganisms on growth and yield of greengram (Phaseolus radiatus), Indian J. Agr. Sci. 72, 421-423.

Piccini A., Azcon R. (1987) Effect of phosphate solubilizing bacteria and vesicular arbuscular mycorrhizal fungi on the utilization of Bayovar rock phosphate by alfalfa plants using a sand vermiculite medium, Plant Soil 101, 45-50.

Pikovskaya R.I. (1948) Mobilization of phosphorus in soil in connection with vital activity of some microbial species, Microbiology 17, $362-370$. 
Poi S.C., Ghosh G., Kabi M.C. (1989) Response of chickpea (Cicer aeritinum L.) to combined inoculation with Rhizobium, phosphobacteria and mycorrhizal organisms, Zbl. Microbiol. 114, 249-253.

Ponmurugan P., Gopi C. (2006) In vitro production of growth regulators and phosphatase activity by phosphate solubilizing bacteria, African J. Biotechnol. 5, 348-350.

Prabakaran J., Ravi K.B., Srinivasan K. (1996) Response of Vamban-1 Blackgram to $\mathrm{N}_{2}$ fixer and $\mathrm{P}$ mobilizers in acid soil, in: Microbiology Abstracts, XXXVII Annual Conference of the Microbiologists of India, IIT, Chennai, Dec., 4-6, p. 120.

Pradhan N., Sukla L.B. (2005) Solubilization of inorganic phosphate by fungi isolated from agriculture soil, African J. Biotechnol. 5, 850854 .

Remy W., Taylor T.N., Hass H., Kerp H. (1994) Four hundred-millionyear-old vesicular arbuscular mycorrhizae, Proceedings of the National Academy of Sciences, USA 91, pp. 11841-11843.

Reyes I., Bernier L., Simard R.R., Antoun H. (1999) Effect of nitrogen source on the solubilization of different inorganic phosphates by an isolate of Penicillium rugulosum and two UV induced mutants, FEMS Micobiol. Ecol. 28, 281-290.

Roos W., Luckner M. (1984) Relationships between proton extrusion and fluxes of ammonium ions and organic acid in Penicillium cyclopium, J. Gen. Microbiol. 130, 1007-1014.

Saber M.S.M., Kabesh M.O. (1990) Utilization of biofertilizers in field crop production. II. A comparison study on the effect of biofertilization or sulphur application on yield and nutrient uptake by lentil plants, Egyptian J. Soil Sci. 30, 415-422.

Saber K., Nahla L., Ahmed D., Chedly A. (2005) Effect of P on nodule formation and $\mathrm{N}$ fixation in bean, Agron. Sustain. Dev. 25, 389393.

Sarojini V., Verma S., Mathur R.S. (1990) The effects of microbial inoculations on the yield of wheat when grown in straw amended soil, Biol. Wastes 33, 9-16.

Sarojini V., Verma S., Mathur M.S. (1989) Biocoenotic association between nitrogen fixing and phosphate solubilizing microorganisms, Curr. Sci. India 59, 1099-1100.

Satizabal E.J.H., Saif U.S.R. (1987) Interaction between vesicular arbuscular mycorrhiza and leguminous Rhizobium in an oxisol of the eastern plains of Colombia, Acta Agron. 7-21.

Sattar M.A., Gaur A.C. (1987) Production of auxins and gibberellins by phosphate dissolving microorganisms, Zbl. Mikrobiol. 142, 393395.

Schreiner R.P., Mishra R.L., Mc Daniel K.L., Benthlenfalvay G.J. (2003) Mycorrhizal fungi influence plant and soil functions and interactions, Plant Soil 188, 199-209.

Shachar-Hill Y., Pfeffer P.E., Douds D., Osman S.F., Doner L.W., Ratcliffe R.G. (1995) Partitioning of intermediary carbon metabolism in vesicular-arbuscular mycorrhizal leeks, Plant Physiol. 108, $7-15$.

Singal R., Gupta R., Saxena R.K. (1994) Rock phosphate solubilization under alkaline conditions by Aspergillus japonicus and A. foetidus, Folia 39, 33-36.

Singh H.P. (1990) Response of dual inoculation with Bradyrhizobium and VAM mycorrhiza or phosphate solubilizer on soybean in mollisol, in: Jalali B.L., Chand H. (Eds.), Trends in mycorrhiza. Research Proceedings of the National conference on Mycorrhiza, HAU, Hisar, India, Feb. 14-16.

Singh H.P., Singh T.A. (1993) The interaction of rock phosphate, Bradyrhizobium, vesicular arbuscular mycorrhizae and phosphate solubilizing microbes on soybean grown in a sub-Himalyan mollisol, Mycorrhiza 4, 37-43.

Son C.L., Smith S.E. (1995) Mycorrhizal growth responses: interaction between photon irradiance and phosphorus nutrition, New Phytol. 108, 305-314.
Snaidr J., Amann R., Huber I., Ludwiig W., Schleifer K.H. (1998) Phylogenetic analysis and in situ identification of bacteria in activated sludge, Appl. Environ. Microb. 63, 2884-2896.

Stevenson F.J. (1986) Cycles of soil carbon, nitrogen, phosphorus, sulphur micronutrients, Wiley, New York.

Subha Rao N.S. (1982) Advances in Agricultural Microbiology, in: Subha Rao N.S. (Ed.), Oxford and IBH Publ. Co., pp. 229-305.

Tinker P.B. (1980) The role of phosphorus in Agriculture, in: Khasawneh F.E., Sample E.C., Kamprath E.J. (Eds.), Soil Sci. Soc. Am. Madison, WI.

Tisdall J.M. (1994) Possible role of soil microorganisms in aggregation in soils, Plant Soil 159, 115-121.

Thiagrajan T.R., Ames R.N., Ahmad M.H. (1992) Response of cowpea (Vigna unguiculata) to inoculated with co-selected vesicular arbuscular mycorrhizal fungi and Rhizobium strains in field trials, Can. J. Microbiol. 38, 573-576.

Tomar S.S., Pathan M.A., Gupta K.P., Khandkar U.R. (1993) Effect of phosphate solubilizing bacteria at different levels of phosphate on black gram (Phaseolus mungo), Indian J. Agron. 38, 131-133.

Trappe J.M. (1987) Phylogenetic and ecologic aspects of mycotrophy in the angiosperms from an evolutionary standpoint, in: Safir G.R. (Ed.), Ecophysiology of VA mycorrhizal plants, Boca Raton, FL, CRC Press, USA, pp. 5-25.

Van Elsas J.D., Van Overbeek L.S ., Fouchier R. (1991) A specific marker pat for studying the fate of introduced bacteria and their DNA in soil using a combination of detection techniques, Plant Soil 138, 49-60.

Vassilev N., Fenice M., Federici F. (1996) Rock phosphate solubilization with gluconic acid produced by immobilized Penicillium variable P16, Biotechnol. Tech. 20, 585-588.

Venkateswarlu B., Rao A.V., Raina P., Ahmad N. (1984) Evaluation of phosphorus solubilization by microorganisms isolated from arid soil, J. Ind. Soc. Soil Sci. 32, 273-277.

Van Veen J.A., Leonard S., Van Overbeek L.S., Van Ellsas J.D. (1997) Fate and activity of microorganisms introduced into soil, Microbiol. Mol. Biol. R. 61, 121-135.

Vasil I.K. (1998) Biotechnology and Food security for 21st century: A real world perspective, Nat. Biotechnol. 16, 399-400.

Vazquez P., Holguin G., Puente M., ELopez Cortes A., Bashan Y. (2000) Phosphate solubilizing microorganisms associated with the rhizosphere of mangroves in a semi arid coastal lagoon, Biol. Fert. Soils 30, 460-468.

Wahid O.A., Mehana T.A. (2000) Impact of phosphate solubilizing fungi on the yield and phosphorus uptake by wheat and faba bean plants, Microbiol. Res. 155, 221-227.

Whitelaw M.A., Harden T.J., Helyar K.R. (1999) Phosphate solubilization in solution culture by the soil fungus penicillium radicum, Soil Biol. Biochem. 32, 655-665.

Whitelaw M.A. (2000) Growth promotion of plants inoculated with phosphate solubilizing fungi, Adv. Agron. 69, 99-151.

Zaidi A. (1999) Synergistic interactions of nitrogen fixing microorganisms with phosphate mobilizing microorganisms, Ph.D. Thesis, Aligarh Muslim University, Aligarh.

Zaidi A., Khan M.S. (2005) Interactive effect of rhizospheric microorganisms on growth, yield and nutrient uptake of wheat, J. Plant Nutr. 28, 2079-2092.

Zaidi A., Khan M.S., Amil M. (2003) Interactive effect of rhizotrophic microorganisms on yield and nutrient uptake of chickpea (Cicer arietinum L.), Eur. J. Agron. 19, 15-21.

Zaidi A., Khan M.S., Aamil M. (2004) Bio-associative effect of rhizospheric microorganisms on growth, yield and nutrient uptake of greengram, J. Plant Nutr. 27, 599-610. 